\title{
Antagonistic Effect and Plant Growth Hormone Produced by Endophyte Bacillus amyloliquefaciens LKM-UL Isolated from Cocoa Plant
}

\author{
Ainon Hamzah ${ }^{1 *}$, Ishak Zubir ${ }^{1,2}$, Ernie Eileen Rizlan Ross ${ }^{3}$, Wan Syaidatul Aqma ${ }^{1}$ \\ ${ }^{1}$ School of Biosciences and Biotechnology, Faculty of Science and Technology, Universiti Kebangsaan \\ Malaysia 43600 Bangi, Selangor, Malaysia. \\ 2 Malaysia Cocoa Board, Cocoa Innovative and Technology Centre, Lot 12621, Kawasan Perindustrian Nilai \\ 71800 Nilai, Negeri Sembilan, Malaysia. \\ 3 Faculty of Applied Sciences, Universiti Teknologi MARA, 40450 Shah Alam Selangor, Malaysia. \\ * Corresponding author. Tel.: 603-89213812 email: antara@ukm.edu.my \\ Manuscript submitted December 12, 2016; accepted March 10, 2017. \\ doi: 10.17706/ijbbb.2017.7.3.169-176
}

\begin{abstract}
In Malaysia black pod disease caused by Phytophthora palmivora is one of the serious problems causing yield loss in cocoa plantation. In this study, an endophytic bacterium living within tissues of healthy Theobroma cacao L. leaves was isolated and assessed its ability to inhibit the growth of P. palmivora. Based on molecular identification using 16S rDNA gene sequences analysis, this endophytic bacterium was identified as Bacillus amyloliquefaciens which was subsequently named as Bacillus amyloliquefaciens LKM-UL. Preliminary test using dual culture method showed B. amyloliquefaciens LKM-UL has strong ability to inhibit the growth of P. palmivora. B. amyloliquefaciens showed the highest antifungal activity after $24 \mathrm{~h}$ incubation in nutrient broth. Cells-free supernatant from B. amyloliquefaciens showed the highest antifungal activity of $30.6 \mathrm{~mm}$ with cell concentration of $\log _{10} 10.63 \mathrm{CFU} / \mathrm{mL}$ via agar disc diffusion method. $B$. amyloliquefaciens LKM-UL also produced plant growth hormone identified as 1-naphthalene acetic acid (NAA), tryptamine, 3-indole propionic acid (IPA), indole-3-butyric acid (IBA), gibberellic acid (GA), trans-zeatin and kinetin.
\end{abstract}

Key words: Antifungal activity, cocoa, endophyte, plant growth hormone.

\section{Introduction}

Cocoa (Theobroma cacao) was first introduced into Malaysia in 1950s to diversify the plantation agriculture after oil palm and rubber. Malaysia today is the fifth largest cocoa grinder in the world and grinding is expected to continue and expand further in future in between 350,000 to 400,000 ha [1]. However, high levels of yield loss to pests and disease is a major problem for world cocoa production in Africa, Brazil and Asia including Malaysia. One of the most threatening fungal pathogen that has significantly dropped the annual pod yield production in Malaysia is the black pod disease caused by Phytophthora palmivora which affects the cocoa pods [2].

In recent years, the use of chemical pesticides to control the disease have been substantial criticism, mainly due to their adverse effects on the environment, human health and other non-target organisms. The use of microbe-based biocontrol agents such as endophytic bacteria is preferable due to their capability to reside inside plants while producing bioactive substances (plant growth regulatory, antibacterial, antifungal, 
antiviral and insecticidal) in enhancing the plant growth and controlling fungal pathogens [3]. The advantages of using endophytic bacteria to control the cocoa pathogen is because they have been adapting to colonization inside the cocoa plants and providing promising suppression of pathogen [4] without causing environmental contamination compared to fungicides and pesticides application [5].

Endophytes also have been used as inoculants to promote plant-growth. The ability of bacterial endophytes to promote plant-growth occurs as a result of direct mechanisms, either facilitates the acquisition of essential nutrients or modulates of level of hormones within a plant [6]. Modulation of hormone levels may cause PGPB (Plant Growth-Promoting Bacteria) synthesizing one or more of the phytohormones such as auxin, cytokinin and gibberellin [7], [8]. The indirect promotion of plant growth occurs when a PGPB decreases the damage to plants following infection with a phytopathogen by inhibiting the growth of pathogen.

In this study, endophytic bacteria from healthy cocoa leaves have been isolated and the antagonistic activities against cocoa fungal pathogen, specifically P. palmivora was evaluated. Subsequently, the selected endophyte was tested for its ability to produce plant-growth hormone.

\section{Methodology}

\subsection{Isolation of Endophytic Bacteria}

The isolations of endophytic bacteria were carried out using the protocol as described by Shimizu [9] with some modifications. Twigs and leaves were collected from healthy cocoa tree grown in Sabah, Malaysia. The surface-sterilized plant pieces were aseptically placed onto nutrient agar (NA) plate and incubated at $28^{\circ} \mathrm{C}$ for 7 days. The colonies appeared around the plant tissues were restreaked onto fresh NA until pure culture was obtained.

\subsection{Characterization and Identification of Endophytic Bacteria}

The selected endophytic bacteria was identified by using morphological, biochemical and molecular procedures [10]. Gram staining was also performed to confirm the purity of the isolate. Molecular genetics identification of the bacterial isolate was performed by amplification of 16S rDNA gene using universal primers (forward [F]: 5-AGAGTTTGATCCTGGCTCAG-3, reverse [R]: 3-GGTTACCTTGTTACGACTT-5). Polymerase chain reaction (PCR) reaction was carried out and the PCR product was purified using a QIAquick PCR purification kit (Qiagen, Valencia, CA, USA). The bacterial 16S rDNA sequences obtained was then aligned with known 16S rDNA sequences in the GenBank database using the basic local alignment search tool (BLASTn) at the National Center for Biotechnology Information (NCBI).

\subsection{Fungal Pathogen Culture P. palmivora}

The cocoa pathogen, P. palmivora was obtained from Malaysia Cocoa Board Culture Collection. Stock cultures of fungal isolate was maintained on potato dextrose agar (PDA) and stored at $4^{\circ} \mathrm{C}$. The working culture was established by transferring the pathogen onto PDA and incubated for 7 days at $30^{\circ} \mathrm{C}$. This culture was used for subsequent experiment.

\subsection{Antagonistic Activity of $B$. amyloliquefaciens LKM-UL against $P$. palmivora}

The antagonistic activity was done via dual culture method [11]. The endophytic bacteria was streaked onto one side of PDA plate, while a $6 \mathrm{~mm}$ x $6 \mathrm{~mm}$ agar cube containing mycelia of cocoa pathogen from 7 days-old culture was placed close to the bacterial streak. The Petri dish was incubated at $30^{\circ} \mathrm{C}$ for one week. The inhibition zones ( $\mathrm{mm}$ ) were recorded by measuring the clear distance between the edges of the fungal mycelium and the bacterial streak. 


\subsection{Determination the Growth of B. amyloliquefaciens LKM-UL and Antagonistic Activity}

The bacterial isolate was inoculated in $100 \mathrm{~mL}$ nutrient broth (NB) in a $250 \mathrm{~mL}$ conical flask and incubated overnight at $28^{\circ} \mathrm{C}$ with agitation at $120 \mathrm{rpm}$. The culture was centrifuged at $4000 \mathrm{rpm}$ for $30 \mathrm{~min}$ and the pellet was suspended in normal saline for preparation of standard inoculums [12]. Subsequently, 10\% ( $/ \mathrm{v}$ ) of standard inoculums of bacterium was transferred into $100 \mathrm{~mL} \mathrm{NB}$ and incubated at $28^{\circ} \mathrm{C}$. The number of bacteria in the culture medium was enumerated using the spread plate method after $8,12,24,36$, and 48 hours of incubation and expressed as colony forming units per milliliter (CFU/mL).

For preparation of cell-free supernatant, $1.0 \mathrm{~mL}$ of culture was then centrifuged at 4,000 rpm for $30 \mathrm{~min}$ at $4^{\circ} \mathrm{C}$. Sterile filter paper disc $(6 \mathrm{~mm})$ was impregnated with $100 \mu \mathrm{L}$ of cell-free supernatants (after filtered through $0.2 \mu \mathrm{m}$ filter) and placed onto 7 days old P. palmivora and incubated for 7 days at $30^{\circ} \mathrm{C}$. The antifungal activity was determined by measuring the inhibition zone of mycelial growth of the pathogen around the filter paper disc.

\subsection{Extraction of Plant Growth Hormones}

The extraction of plant growth hormone was performed by method adapted from Miezah [13]. $B$. amyloliquefaciens was grown in $100 \mathrm{~mL}$ of nutrient broth in $500 \mathrm{~mL}$ conical flask and incubated at $28 \pm 2{ }^{\circ} \mathrm{C}$ with agitation of $120 \mathrm{rpm}$ for 24 hours. The culture was centrifuged at 7,700 x g for 30 minutes. The cell-free supernatant was reduced to $50 \mathrm{~mL}$ by evaporation under vacuum and adjusted to $\mathrm{pH} 2.8 \mathrm{using} 1 \mathrm{~N}$ $\mathrm{HCl}$. The plant growth hormone from cell-free supernatant was extracted using ethyl acetate to produce ethyl acetate fraction and aqueous fraction. Ethyl acetate fraction was evaporated under vacuum and dissolved in absolute methanol for thin layer chromatography (TLC) and high pressure liquid chromatography (HPLC) bioassay. Aqueous fraction was adjusted to $\mathrm{pH} 7.0 \mathrm{using} 1 \mathrm{~N} \mathrm{NaOH}$ and further extracted with water-saturated $n$-butanol. Fraction of $n$-butanol was separated and evaporated under vacuum and dissolved in absolute methanol for TLC and HPLC bioassay.

\subsection{Detection Plant Growth Hormones Using Thin Layer Chromatography (TLC)}

TLC chromatogram was run on $3 \mathrm{~cm}$ width $\times 10 \mathrm{~cm}$ length preparative silica gel plates (Gel silica 60GF $\mathrm{GF}_{25}$, Merck). The solvent system used were chloroform:ethyl acetate:formic acid (50:40:10, v/v) to separate indole compounds and gibberellins in ethyl acetate fractions. Another solvent $n$-butanol:acetic acid:water $(12: 3: 5, v / v)$ was used to separate cytokinin in $n$-butanol fraction. One $\mathrm{mL}$ of fraction was spotted onto TLC plate, air-dried then subjected to the devolving solvent as mobile phase. The plates were then visualized under the UV light at wavelength $254 \mathrm{~nm}$. Besides that, the plate was exposed to iodine vapour in a closed jar containing iodine crystals [14]. The relative fluidity $\left(R_{f}\right)$ value of each separated spots were measured.

\subsection{Identification of Plant Growth Hormones by High Pressure Liquid Chromatography (HPLC)}

HPLC chromatogram was produced by injecting $10 \mu \mathrm{l}$ of the filtered extracts onto a reverse-phase column (Nucleosil EC 300/4 100-10 $\mathrm{C}_{18}$ ) using JASCO ChromPass Chromatography System (JAPAN), equipped with Photo Diode Array (MD 2010 plus) at $254 \mathrm{~nm}$. Two solvent systems were used to separate hormones compounds. Solvent A was $85 \%$ of water:acetonitrile:acetic acid (85:15:1, v/v) and solvent B was 15\% of 30\% methanol in water, with flow rate of $1.0 \mathrm{~mL} / \mathrm{min}$. Retention times for peaks were compared to hormones standard; 3-indole acetic acid (IAA-Sigma), 1-naphthalene acetic acid (NAA-Sigma), indole-3-butyric acid (IBA-Sigma), 3- indole propionic acid (IPA-Aldrich), tryptamine (TRY-Aldrich), trans-zeatin (Sigma), kinetin (Sigma) and gibberellic acid (GA-Sigma).

\section{Results and Discussion}


Several endophytic bacteria that colonize inside plant tissues were successfully isolated from surface-sterilized of healthy cocoa twigs along with leaves. One of the isolate (designated as LKM-UL) showed strong inhibition distance of $32.2 \mathrm{~mm}$ against P. palmivora. The morphological and biochemical characterization showed the bacteria appeared as opaque colonies on the NA medium and Gram positive-rod. The isolate exhibited positive results for motility, catalase and Voges Proskauer tests but negative for methyl red.

The result of the 16S rDNA gene showed 100\% similarity of isolate LKM-UL with Bacillus amyloliquefaciens, and thus designated as Bacillus amyloliquefaciens LKM-UL. The 16S rDNA sequence was submitted to GenBank with the accession number of KR560041.

The growth of $B$. amyloliquefaciens LKM-UL and the ability to inhibit cocoa pathogen from cells-free extract is showed in Fig. 1. Inhibitory activity was detected from the beginning of the cells growth, during exponential and stationary phases. The highest antagonistic activity was observed in the early stationary phase of bacterial growth obtained at 24 hours of incubation period. The optimum inhibition zone (30.6 $\mathrm{mm}$ ) was concurrent with the optimum cells growth ( $\left.\log _{10} 10.63 \mathrm{CFU} / \mathrm{mL}\right)$. Further incubation period showed a decreased in the antagonistic ability and also the cells growth. The ability of B. amyloliquefaciens to reduce the mycelial growth of P. palmivora reveals certain substances produced by the bacterium that has fungistatic effect.

This finding is in accordance with previous reports, in which endophytic bacteria produced antifungal to protect plant from pathogens. Endophytic bacterium, Bacillus subtilis strain EDR4 showed inhibitory effect on stem rot caused by Sclerotinia sclerotiorum [15]. Meanwhile, Bacillus amyloliquefaciens isolated from tomatoes acquired longer cultivation periods of 48 hours to inhibit Alternaria solani, a pathogenic fungus which caused early blight in tomato [16]. The rapid growth of endophytic bacteria offered advantage in the race for space and nutrients against pathogenic fungi, before any antifungal activity was deployed [17].

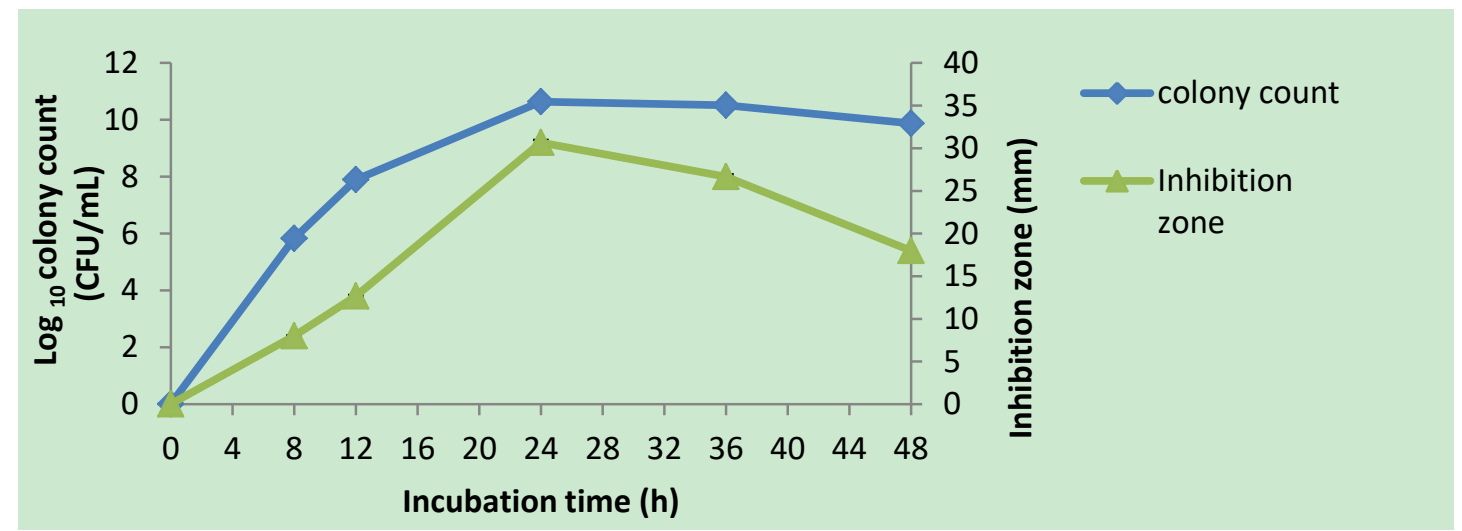

Fig. 1. The growth of B. amyloliquefaciens LKM-UL and inhibition zones of cells-free supernatant against cocoa pathogen.

Plant growth hormones extracted from B. amyloliquefaciens LKM-UL using ethyl acetate fraction on TLC plate showed three clear individual spots and several faded spots of indole (auxins) and gibberellins hormones (Fig 2a). The clear spots detected at $R f$ value of $0.3,0.7$ and 0.9 . The faded spots were due to the type of solvent used for separation of indole compounds which damaged some hormones [18]. Azospirillum brasilense produced substance associated with auxin activity in cell-free supernatant which can be spotted by TLC apparatus [19]. Meanwhile, the $n$-butanol fraction revealed cytokinin spot detected at $R f$ value of 0.5 , 0.7 and 0.9 (Fig. 2b). Cytokinin has been observed in several bacteria including Rhizobium sp., Bacillus subtilis BC1 and Escherichia coli K12 by TLC method showing $R f$ value of 0.65 [20]. 


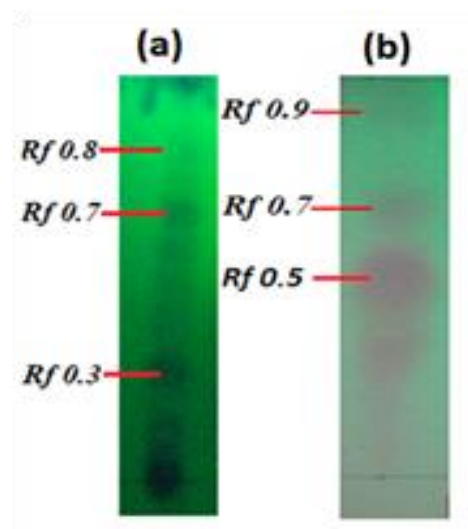

Fig. 2. TLC chromatogram of B. amyloliquefaciens LKM-UL from (a) Ethyl acetate fraction and (b) $n$-butanol fraction showing different $\mathrm{R}_{\mathrm{f}}$ values.

Identification of indole (auxin) and gibberellins hormones from ethyl acetic fractions using HPLC revealed that, B. amyloliquefaciens LKM-UL produces NAA, TRY, IPA, IBA and GA (Fig 3a). Meanwhile, the cytokinin hormones from $n$-butanol fraction showed that the isolate produced trans-zeatin and kinetin (Fig 3b). Other study showed Bacillus subtilis LK14 isolated from Moringa peregrine plant produced auxin hormones that can improved the growth of Solanum lycopersicum [21]. Auxin hormones were known to play important role in cell elongation, division and enlargement [22] and GA could stimulated the shoot length, chlorophyll contents and increased biomass of rice plant [23]. Interestingly, B. amyloliquefaciens LKM-UL isolated from cocoa plant have the ability to produce multiple types of auxins (1-naphthalene acetic acid, tryptamine, 3-indole propionic acid and indole-3-butyric acid), gibberellic acid and cytokinins (trans-zeatin and kinetin). These growth-promoting hormones (auxin, cytokinins, gibberellic acid, and abscisic acid) either inhibit or potentiate stress-specific hormones in mediating the protection or susceptibility of the plant against the invading pathogen [24].

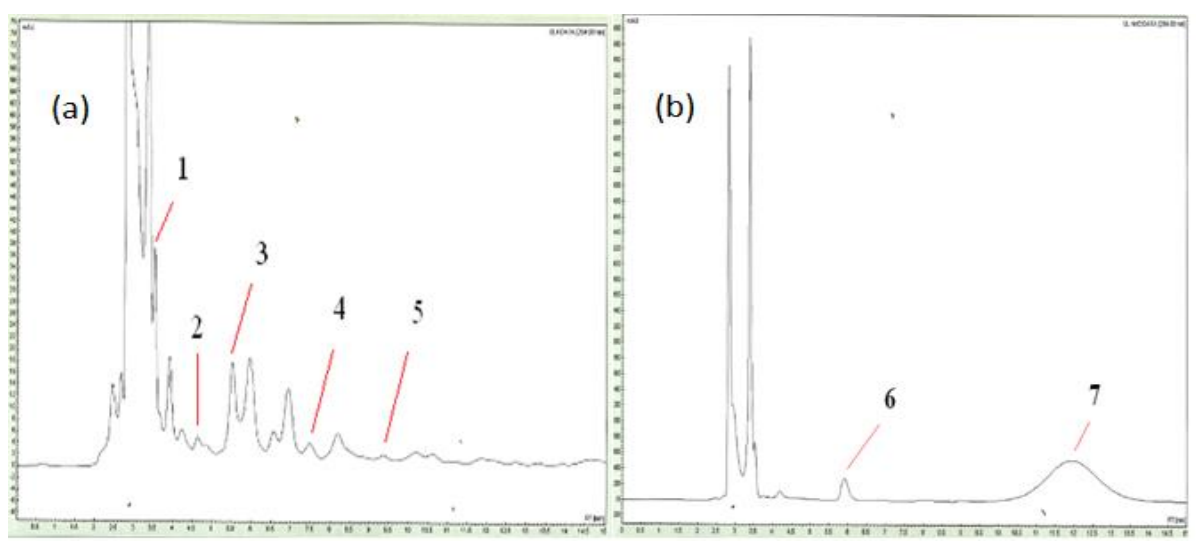

Fig. 3. HPLC chromatograms of B. amyloliquefaciens LKM-UL showed plant growth hormones from (a) ethyl acetate fraction and (b) n-butanol fraction; 1: NAA, 2: TRY, 3 IPA, 4: IBA, 5: GA, 6: Trans-zeatin and 7: Kinetin.

\section{Conclusion}

Endophytic bacteria have been reported to live in symbiosis within diverse plants but their known function is still limited. Since B. amyloliquefaciens LKM-UL exhibit antifungal activity against $P$. palmivora and also producing several growth hormones, therefore it can be developed as potential biocontrol and 
biofertilizer for cocoa plant.

\section{Acknowledgment}

This study was supported by Intensive Research in Priority Area (IRPA) of Ministry of Sciences, Technology and Environment of Malaysia.

\section{References}

[1] Lee, C. H., (2013). Planting cocoa-challenges and reality in Malaysia. Retrieved from the website: (http://www.iipm.com.my/ipicex2014/docs/2012/oral/PLANTING\%20COCOA-\%20CHALLENGES\%2 0AND\%20REALITY\%20IN\%20MALAYSIA.pdf)

[2] Acebo-Guerrero, Y., Hernandez-Rodriguez, A., Heydrich-Perez, M., Jaziri, M., \& Hernandez-Lauzardo, A. N. (2012). Management of black pod rot in cocoa (Theobroma cocoa L.). A review. Fruits, 67(1), 41-48.

[3] Li, H., Soares, M. A., Torres, M. S., Bergen, M., \& White, J. F. (2015). Endophytic bacterium, Bacillus amyloliquefaciens, enhances ornamental hosta resistance to diseases and insect pests. Journal of Plant Interactions, 10(1), 224-229.

[4] Lin, T., Zhao, L., Yang, Y., Guan, Q., \& Gong, M. (2013). Potential of endophytic bacteria from Sophora alopecuroides nodule in biological control against Verticillium wilt disease. Australian Journal of Crop Science, 7, 139-146.

[5] Paul, N. C., Ji, S. H., Deng, J. X., \& Yu, S. H. (2013). Assemblages of endophytic bacteria in chili pepper (Capsicum annuum L.) antifungal activity against phytopathogens in vitro. Plant Omics Journal, 6(6), 441-448.

[6] Santoyoa, G., Moreno-Hagelsiebb, G., Orozco-Mosquedac, M. C., \& Glickc, B. R. (2016). Microbiological Research, 183, 92-99.

[7] Bottini, R., Cassan, F., \& Piccoli, P. (2004). Gibberellin production by bacteria and its involvement in plant growth promotion and yield increase. Applied Microbiology Biotechnology, 65, 497-503.

[8] Tien, T. M., Gaskin, M. H., \& Hubbell, D. H. (1979). Plant growth substances produced by Azopirillum brasilense and their effect on the growth of pearl millet (Pennisetum americanum L.). Applied and Environmental Microbiology, 37, 1016-1024.

[9] Shimizu, M., Nakagawa, Y., Sato, Y., Furumai, T., Igarashi, Y., Onaka, H., et al. (2000). Studies on endophytic actinomycetes (I) Streptomyces sp. isolated from Rhododendron and its antifungal activity. Journal Genetic Plant Pathology, 66, 360-366.

[10] Cappuccino, J. G., \& Sherman, N. (2005). Microbiology: A Laboratory Manual, 8th Edition. Pearson/Benjamin Cummings Publishing Company, Inc.

[11] Shin, D. S., Park, M. S., Jung, S., Lee, M. S., Lee, K. H., Bae, K. S., et al. (2007). Plant growth-promoting potential of endophytic bacterial isolated from roots of coastal sand dune plants. Journal of Microbiology and Biotechnology, 17, 1361-1368.

[12] Ainon, H., Amir, R., Raja Farzarul, H. R. A., \& Noor, A. Y. (2010). Isolation and characterization of bacteria degrading Sumandak and South Angsi Oils. Sains Malaysiana, 39(2), 161-168.

[13] Miezah, K., Ofosu-Anim, J., Budu, G.K.O., Enu-Kwesi, L., \& Cofie, O. (2008). Isolation and identification of some plant growth promoting substances in compost and co-compost. International Journal of Virology, 4, 30-40.

[14] Atalla, M., Zeinab, H. K., Eman, R. H., Amani, A. Y., \& Abeer, A. A. (2008). Production of some biologically active secondary metabolites from marine-derived fungus, Varicosporina ramulosa. Malaysia Journal of Microbiology, 4(1), 14-24.

[15] Chen, Y., Gao, X., Chen, Y., Qin, H., Huang, L., \& Han, Q. (2014). Inhibitory efficacy of endophytic Bacillus 
subtilis EDR4 against Sclerotinia sclerotiorum on rapeseed. Biological Control, 78, 67-76.

[16] Yi, Y. J., Li, Y. S., Xia, B., Li, W. P., Pang, L., \& Tong, Z. D. (2015). Optimization of medium composition and culture conditions for antifungal activity of a tomato endophytic bacterium. Biological Control, 82, 69-75.

[17] Zivkovic, S., Stojanovic, S., Ivanovic, Z., Gavrilovic, V., Popovic, T., \& Balaz, J. (2010). Screening of antagonistic activity of microorganisms against Colletotrichum acutatum and Colletrichum gloeosporioides. Archives of Biological Science Belgrade, 62(3), 611-623.

[18] Schneider, E. A., Gibson, R. A., \& Wightman, F. (1972). Biosynthesis and metabolism of indole-3yl-acetic acid. 1. The native indoles of barley and tomato shoots. Journal of Experimental Botany, 23, 152-170.

[19] Martinez-Morales, L. J., Soto-Urzua, L., Beatriz, E. B., \& Sanchez-Ahedo, J. A. (2003). Indole-3-butyric acid (IBA) production in culture medium by wild strain Azospirillum brasilense. FEMS Microbiology Letters, 228,167-173.

[20] Sabat, S., Murthy, V. K., Shantha, S. L., Kushnoor, D., Agarwal, G., Thomas, J., et al. (2014). Comparative study of cytokinin production isolated from bacteria and shoot induction. Indian Journal of Biotechnology, 13, 544-546.

[21] Khan, A. L., Halo, B. A., Elyassi, A., Ali, S., Al-Hosni, J., Hussain, J., et al. (2016). Indole acetic acid and ACC deaminase from endophytic bacteria improves the growth of Solanum lycopersicum. Electronic Journal of Biotechnology, 21, 58-64.

[22] Ishida, Y., Nakamura, A., Mitani, Y., Suzuki, M., Soeno, K., Asami, T., et al. (2013). Comparison of indole derivatives as potential intermediates of auxin biosynthesis in Arabidopsis. Plant Biotechnology, 30, 185-190.

[23] Waqas, M., Khan, A. L., \& Lee, I. J. (2014). Bioactive chemical constituents produced by endophytes and effects on rice plant growth. Journal of Plant Interactions, 9(1), 478-487.

[24] Naseem, M., Philippi, N., Hussain, A., Wangorsch, G., Ahmed, N., et al. (2012). Integrated systems view on networking by hormones in Arabidopsis immunity reveals multiple crosstalk for cytokinin. Plant Cell, 24, 1793-1814.

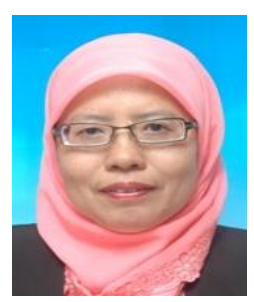

Ainon Hamzah obtained her doctorate in microbial biotechnology from Universiti Putra Malaysia (UPM). Currently she is a professor in School of Biosciences and Biotechnology, Universiti Kebangsaan Malaysia (UKM). Her interest is in the field of environmental microbiology and biotechnology, particularly in bioremediation of hydrocarbon, heavy metals and plants endophytes.

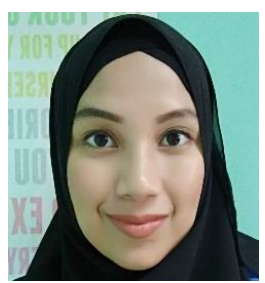

Wan Syaidatul Aqma Wan Mohd Noor received her PhD from Dublin City University, Ireland in environmental microbiology. Her research interests bacterial aggregation, biofilms, bacteria stress response. She is a senior lecturer at School of Biosciences and Biotechnology, UKM.

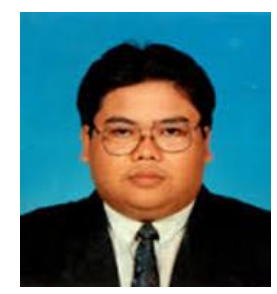

Ishak Zubir obtained his masters of science from Universiti Kebangsaan Malaysia. He is currently working as research officer at Malaysian Cocoa Board while pursuing his $\mathrm{PhD}$ at UKM. His research interests in endophytic microorganisms. 


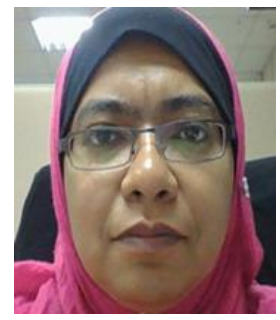

Ernie Eileen Rizlan Ross obtained her masters of science from Universiti Putra Malaysia. She is currently a lecturer at Universiti Teknologi MARA. Her research interest is in microbial molecular biology. 